\title{
Decellularized Extracellular Matrix
}

\author{
SooHwa Jang ${ }^{1,2}$, Monica Michel ${ }^{1,2}$, Rahulkumar Bhoi ${ }^{1,2}$, Kyung-Hwan Jung, ${ }^{3,4}$ and Nam-Soo Kim ${ }^{1,2 *}$ \\ ${ }^{1}$ Printing Nano Engineering lab, The University of Texas, USA \\ ${ }^{2}$ Department of Metallurgical, The University of Texas at El Paso, USA \\ ${ }^{3}$ Gangwon Regional Division, Korea Institute of Industrial Technology, Korea
}

Submission: March 02, 2017; Published: March 27, 2017

*Corresponding author: Nam-Soo Kim, Department of Metallurgical, The University of Texas, Materials and Biomedical Engineering, The University of Texas at El Paso, USA, Tel: +1-915-747-7996; Fax: +1-915-747-8036; E-mail: nkim@utep.edu

\section{Abstract}

It has been demonstrated that extracellular matrix (ECM) has a critical role in promoting the cell proliferation, cell growth and repair of organs after damage. A decellularization process has been developed to maintain the intact structure of the ECM, while efficiently eliminating the cellular components that lead to minimization the immune-related adverse effects. We have successfully developed a decellularization protocol using porcine adipose tissues. The DNA and cellular contents was not found in the decellularized ECM and in situ structure was greatly preserved.

\section{What is the Extracellular Matrix}

Extracellular matrix (ECM) is one of the fundamental structures that maintain the cells in tissues. It is a gel-like material of proteins and polysaccharides which have a unique composition depending on the types of tissues [1,2,5]. ECMs are commonly used in the tissue engineering field for the reconstruction of organs and surgical applications. It provides excellent microenvironment to enhance the cell proliferation, migration and differentiation [2].

\section{Decellularization process}

Decellularization protocols have been used to extract ECM from intact adipose tissue. It is the best choice for eliminating xenogeneic epitopes from naïve porcine tissues while maintaining their ECM composition including collagen, glycosaminoglycan (GAGs), fibronectin, and elastin. The main goal of the decellularization process is to efficiently remove all xenogeneic cellular antigens, which can cause adverse effects such as inflammatory response or immune-mediated rejection of the host tissues $[1,3,4]$.

\section{Description of the process}

Porcine adipose tissues were purchased from local market in El Paso and were kept frozen at $-80^{\circ} \mathrm{C}$ until use. Tissues were taken out from the freezer and thawed overnight and ground to make into a pasty mixture. The tissue was then placed in a beaker containing ultrapure water for 2 days. After that, $0.5 \mathrm{M} \mathrm{NaCl}$ and $1 \mathrm{M} \mathrm{NaCl}$ solution were prepared to immerse the tissue for 4 hours in each, respectively. Next, tissues were decellularized by being sequentially washed with ultrapure water, $0.25 \%$ trypsin, triton X-100, 1-propanol, and ultrapure water. The final ECM product was shown to be a white, clean and fibrous structure after lyophilization. It was either used immediately for further experiments, or otherwise stored in a sterile phosphate-buffered saline solution at $4{ }^{\circ} \mathrm{C}$ until use.

\section{Evaluating the decellularization efficiency}

Methods have been well established to evaluate the decellularized ECM [1-8]. Fluorescence-based analysis has mostly been used to confirm the residual DNA contents. In addition to them, decellularized samples of ECM were analyzed histologically to view the structure of the decellularized ECM in situ, and compared to intact porcine adipose tissues. The DNA content of the decellularized ECM was negligible $(1.28 \pm 0.3 \mathrm{ng} /$ mg dry ECM) and the residual cellular components were stained by 4,6-diamino-2-phenylindole and hematoxylin and eosin. After decellularization, the structure of ECM seemed similar compared to the naïve adipose tissues and nuclei were not detected. Furthermore, common types of collagen in adipose tissues such as collagen I, II, III, and IV were strongly detected and showed to have sustained their structure.

\section{Conclusion}

This study reports the efficient process of porcine adipose tissue-derived extracellular matrix. While it is still required to demonstrate in vitro and in vivo biocompatibility of the decellularized ECM for further applications, this method could 
provide with xenogeneic biomaterials and might have a chance to be applied in regenerative medicine.

\section{Acknowledgment}

This research was supported by the National Research Council of Science \& Technology (NST) grant by the Korea government (MSIP) (CRC-15-03-KIMM). Thanks to Dr. Thomas Boland for allowing the use of biomedical laboratory to conduct research.

\section{References}

1. Choi YC, Choi JS, Kim BS, Kim JD, Yoon HI, et al. (2012) Decellularized Extracellular Matrix-Derived from Porcine Adipose Tissue as a Xenogeneic Biomaterial for Tissue Engineering. Tissue Eng Part C Methods 18(11): 866-876.

2. Crapo PM, Gilbert TM, Badylak SF (2011) An overview of tissue and whole organ decellularization processes. Biomaterials 32(12): 32333243.
3. Pati F, Jang JN, Cho DW (2014) Printing three-dimensional tissue analogues with decellularized extracellular matrix bioink. Nature Communications. Article number: 3935 (2014).

4. Brown BN, Freund JM (2011) Comparison of Three Methods for the Derivation of a Biologic Scaffold Composedof Adipose Tissue Extracellular Matrix. Tissue Eng 17(4): 411-421.

5. Bosman FT, Stamenkovic I (2003) Functional structure and composition of the extracellular matrix. J Pathol 200(4): 423-428.

6. Vorotnikova E, McIntosh D (2010) Extracellular matrix-derived products modulate endothelial and progenitor cell migration and proliferation in vitro and stimulate regenerative healing in vivo. Matrix Biol 29(8): 690-700.

7. Gilbert TW, Sellaro TL (2006) Decellularization of tissues and organs. Biomaterials 27(19): 3675-3683.

8. Roosens A, Somers P (2016) Impact of Detergent-Based Decellularization Methods on Porcine Tissues for Heart Valve Engineering. Ann Biomed Eng 44(9): 2827-3289.

\section{Your next submission with Juniper Publishers} will reach you the below assets

- Quality Editorial service

- Swift Peer Review

- Reprints availability

- E-prints Service

- Manuscript Podcast for convenient understanding

- Global attainment for your research

- Manuscript accessibility in different formats

( Pdf, E-pub, Full Text, Audio)

- Unceasing customer service

Track the below URL for one-step submission https://juniperpublishers.com/online-submission.php 